\title{
Paikantumia naisyrittäjyyden, yrittäjyys- ja aikuiskasvatuksen keskusteluihin
}

\author{
SEIJAKESKITALO-FOLEY
}

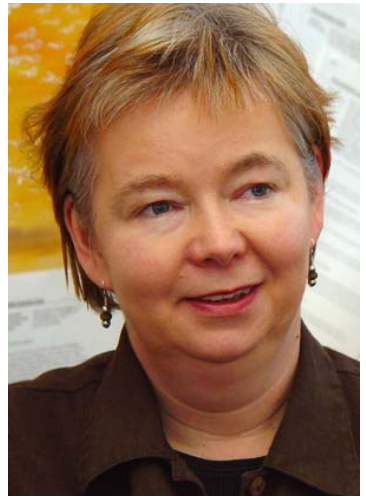

Kirjoittajan tutkimuksellisen kiinnostuksen kohteena on Lapissa naisille suunnattujen yrittäjyyshankkeiden yhteydessä toteutettava aikuiskoulutus. Artikkelissa tarkastellaan yrittäjyyden sukupuolta sekä yrittäjyys- ja aikuiskasvatusta koskevaa tutkimusta lukemalla kutakin teemaa koskevia määrittelyjä, suuntauksia ja ajallisia jäsennyksiä. Kirjoittaja problematisoi yrittäjyyskäsitettä sekä sukupuolen tutkimuksen että yrittäjyyskasvatuksen näkökulmasta. äestön ja talouden toimintojen keskittämiseen johtavalla politiikalla on ollut Suomen Lapille monenlaisia seurauksia.1990-luvulla alkanut Lapin nopea taloudellinen ja yhteiskunnallinen muutos, julkisen sektorin alasajo ja työmarkkinoiden uudelleen rakenteistuminen ovat kiihdyttäneet osaltaan myös poismuuttoa alueelta. Muutoksella on sukupuolistunut luonne: ensinnäkin muuttotappion vuoksi naisten määrä lappilaisella maaseudulla vähenee ja toiseksi: julkisten palvelujen alasajo on vähentänyt naisten työmahdollisuuksia palkansaajina. Yrittäjyyttä tarjotaan ratkaisuksi tähän rakennemuutokseen. Naisten yrittäjiksi kannustaminen voidaan nähdä osana yleistä koulutuspolitiikan linjausta, mutta myös aluepolitiikkana ja sukupuolten tasa-arvon valtavirtaistamispolitiikkana. Yrittäjyyskasvatuksen lisäämistä kaikilla koulutusasteilla on korostettu 2000-luvulla suomalaisessa koulutuspolitiikassa ${ }^{1}$ (Opetusministeriön...2004, 8). Aikuiskoulutuksena yrittäjyyskasvatusta on suunnattu naisille erityisesti Euroopan unionin tukemissa hankkeissa.

Osallistun naisyrittäjyyskoulutusta koskevaan keskusteluun meneillään olevassa tutkimuksessani, joka koskee Lapissa naisille suunnatuissa hankkeissa toteutettua aikuiskoulutusta. Tutkimus on osa laajempaa hanketta ${ }^{2}$, jossa tutkitaan yrittäjäminää (enterprising self, ks. esim. Rose 1992) ja sosiaalisia eroja tuottavia käytäntöjä. Tutkimusaineistoni ${ }^{3}$ koostuu hallinnollisista teksteistä sekä naisyrittäjyyshankkeita organisoineiden ja näihin hankkeisiin osallistuneiden naisten haastatteluista. Tutkimuksessani tarkastelen sekä naisyrittäjyyskoulutusta koskevia diskursseja että naisyrittäjyyshankkeiden koulutuksiin osallistuneiden yrittäjyydelle tuottamia merkityksiä. Tämä artikkelini pohjautuu tarpeeseen selvittää niitä taustaolettamuksia ja tulkintoja, jotka ovat aiheeni kannalta tärkeitä. Tarkastelen yrittäjyyden sukupuolta sekä yrittäjyys- ja aikuiskasvatusta koskevaa tutkimusta lukemalla kutakin teemaa koskevia määrittelyjä, suuntauksia ja ajallisia jäsennyksiä: Millaiseen keskusteluavaruuteen ja käsitemaastoon tutkimukseni voi sijoittua? Millaisia jännitteitä keskusteluissa on tuotettu?

Tarkastelunäkökulmani paikantuu lähinnä uusliberalistisen koulutus- ja työmarkkinapolitiikkaa kritisoivaan keskusteluun. Uusliberalismilla ${ }^{4}$ viittaan käytäntöihin, joilla valtio harjoittaa poliittista hallintaa ja kohdistaa sen yksilöihin (Kantola 2002, 28). Paikantumisella viittaan myös sukupuolen ja maantieteellisen alueen virittämään pohdintaan. 
Aluksi esittelen yleisesti naisyrittäjyyskoulutushankkeiden taustoja ja tavoitteita.

\section{Yrittäjyys maaseudun naisten mahdollisuutena}

Suomessa naisyrittäjyyttä koskevia koulutushankkeita on toteutettu 1990-luvulta asti erityisesti Euroopan unionin rahoitustuen turvin. Lähes kaikkiin eri puolille Suomea perustettuihin resurssikeskuksien toimintaan ja hankkeisiin sisältyi naisyrittäjyys. Euroopan unionin kasvun ja työllisyyden edistämisen strategiaan kuuluvassa alueiden kehittämisessä korostetaan naisten toiminnan merkityksen lisäämistä työmarkkinoilla sekä työntekijöinä että yrittäjinä. Paikallisten ja alueellisten naisten resurssikeskuksien tehtävänä on työskentely naisten ja alueen hyväksi. (Westman 2006.)

Naisille suunnattua yrittäjyyskoulutusta on Suomessa toteutettu kuitenkin jo aiemmin, ensimmäinen työllisyysvaroin järjestetty naisyrittäjäkurssi toteutettiin Vammalassa 1988-1989. Myös Ruotsissa ja Norjassa naisille suunnattua yrittäjäkoulutusta on ollut tarjolla valtion tukemana jo aiemmin. Näillä koulutuksilla on ollut myös alueellinen merkitys, sillä naisyrittäjyyteen tukeminen on nähty keinona muun muassa pohjoisen maaseudun elinvoimaisuuden ylläpitoon. (Räsänen 1990, 11.) Tämä alueellinen teema on toistunut myös suomalaisen maaseudun naisyrittäjyyttä tarkastelevissa tutkimuksessa (ks. esim. Ikonen 2003 ja 2008; Keskitalo-Foley, Komulainen \& Naskali 2007; Komulainen 2004; Koski \& Tedre 2004). Niissä on viitattu niin sanottuun pelastusdiskurssiin, jossa sekä nainen että maaseutu on nimetty emansipoinnin kohteiksi: ”naisyrittäjyyttä voidaan milteipä väittää vuosituhannen taitteen maaseudun pelastusopiksi ” (Koski \& Tedre 2004, 124). Yrittäjyys on tarjolla naisille kouluttautumisen tavoin emansipatorisena ${ }^{5}$ mahdollisuutena.

Samoin kuin koulutusta, voi myös yrittäjyyttä tarkastella yhtäläisten mahdollisuuksien tasa-arvon ja yhtäläisten tulosten tasa-arvon kannalta. Yhtäläiset mahdollisuuksien tasa-arvoajattelun mukaan yhteiskunnan tehtävänä on luoda yhtäläiset mahdollisuudet kaikille toteuttaa omaa potentiaaliaan. Tällöin oletetaan, että on yksilöstä itsestään kiinni, miten hän käyttää mahdollisuuksiaan. Yhtäläisten tulosten tasa-arvo kiinnittää huomiota niihin yhteiskunnallisiin rakenteisiin ja kulttuurisiin oletuksiin, jotka estävät yksilöitä to- teuttamasta mahdollisuuksiaan. (Holli 2002, 17.)

Taloudellisten ja sosiaalisen tasa-arvon lisäksi esiin onkin nostettu kulttuurinen tasa-arvo. Sillä viitataan erilaisten yhteiskunnallisten ryhmien laajempaan yhteiskunnalliseen arvostukseen ja heidän yhtäläisten oikeuksiensa toteuttamiseen sekä identiteettipolitiikkaan. Kulttuurisen tasa-arvon vaatimus on erityisen tärkeä vallan kannalta marginaalisille ryhmille, joita ovat esimerkiksi naiset sekä etniset ja seksuaaliset vähemmistöt. Tällöin tasa-arvon tavoittelu edellyttää kulttuuristen oletusten ja yksilöiden asenteiden haastamista ja muuttamista. (Emt., 16.)

Perinteinen sukupuolijärjestelmä työn- ja vallanjakoineen tuottaa erilaiset materiaaliset ja symboliset tilat naisille ja miehille. Sen osoittama toimijuuden tila maaseudun naisille voi osoittautua naisyrittäjänäkin kapeaksi. Hanna-Mari Ikonen $(2008,68)$ huomauttaa maaseudun naisyrittäjyysdiskurssin essentialismin ja uuskonservatiivisuuden vaarasta silloin, kun siinä oletetaan naisten piiriksi huolehtimisen ja pelastamisen kohteena olevan maaseutu. Tämä diskurssi voi uusintaa "luonnollistettua” perinteistä sukupuolijärjestystä. Yrittäjyyskasvatuksen ja naisyrittäjyyden jännite rakentuukin yhtäältä emansipoivana toimintana, mutta toisaalta ihmisiä luokittelevana ja tiettyyn järjestykseen asettavana (Komulainen 2007, 126) ja toiseutena (Koski \& Tedre 2004, 132-133).

Seuraavaksi avaan yrittäjyyden sukupuolta sekä yrittäjyys- ja aikuiskasvatusta koskevaa tutkimusta, jossa tarkastelen näiden teemojen määrittelyjä, suuntauksia ja ajallisia jäsennyksiä.

\section{Yrittäjyyden sukupuoli}

Yrittäjyyden tutkimus avaa monitulkintaisen käsiteavaruuden, voidaanhan jo sanalla "yritys" viitata yhtä hyvin yksin työskentelevään käsityöläiseen kuin ylikansallisiin suuryrityksiin. Näiden yritysten maailmoissa lienee varsin vähän yhtymäkohtia. Yrittäjyyden tutkimusta on vielä muutama vuosikymmen sitten tehty sukupuolineutraalisti kiinnittämättä huomiota siihen, miten sukupuoli mahdollisesti jäsentää yrittäjyyttä (ks. esim. Kyrö 2004). Sen sijaan nykyään yrittämisestä näyttäisi vallalla olevan käsityksen mukaan olevan kahdenlaista: yrittäjien yrittäjyyttä ja naisyrittäjien naisyrittäjyyttä. Tämä jako näkyy yrittämisen kentällä niin tutkimuksessa kuin politiikan teossa sekä populäärikirjallisuudessa että neuvontapalveluis- 
sa (Pietiläinen 2007, 7-8). Sekä 'naisen' että ’yrittäjyyden’ käsite vaativat avaamista.

Naisten yrittäjyyttä koskevia tutkimustekstejä feministisen dekonstruktion avulla analysoineen Helene Ahlin (2004) mukaan 'yrittäjän' ja 'yrittäjyyden' käsitteillä ei ole olemassa yhtä yhtenäistä määritelmää. Vaikka yhteisymmärrystä yrittäjyyden määrittelystä ei Ahlin analysoimissa tutkimuksissa synny, ne tuottavat kuitenkin joitakin yhteisiä olettamuksia. Analyysin mukaan yrittäjyys määrittyy positiivisena. Toisena yhdistävänä oletuksena on määrän arvottaminen, "paljon on parempi kuin vähän”, mikä heijastuu esimerkiksi yrityskoon arvottamiseen. Kolmanneksi, yrittäjyys määrittyy miehiseksi, ei pelkästään yksilöä vaan myös organisaatiota ja yhteiskuntaa koskevana. (Ahl 2004, 61.) Naisyrittäjiä ja -yrittäjyyttä eri lähtökohdista tutkineet (Kyrö 2004; Ljungren \& Nilsson 1995) ovat yksimielisiä siitä, että perinteinen yrittäjyyden malli on miehinen: miehiin verrattuna naiset määrittyvät tässä mallissa marginaaliksi (Kovalainen 1993) ja toisiksi (Ahl 2004, 173), ja naisten tekemä työ jää näkymättömäksi (Jääskö 2000).

Naisyrittäjyystutkimusta voidaan hahmottaa ajallisesti toisiaan seuraavina vaiheina. Paula Kyrö (2004, 299-302) on jäsentänyt naisyrittäjyyden tutkimuksen kolmeksi aalloksi. Ensimmäisen aalto "Miesten todellisuus ihanteena ja perustana naisyrittäjyystutkimukselle" kuvaa 1970-luvun tilannetta, jolloin yrittäjyyttä näennäisesti sukupuolineutraalisti tutkittaessa tutkittiin itse asiassa miesyrittäjyyttä. Piirreteoreettisin teorioin pyrittiin identifioimaan sellaisia yksilöitä, jotka yrittäjinä edistivät makrotalouden vaurastumista. Keskeisenä lähtökohtana oli, että yrittäjäominaisuuksia omaavat yksilöt saivat aikaan liiketoimintaa, joka puolestaan tuotti kansantalouden kasvua. Yrittäjyyden ihanteeksi muotoutui taloudellisia riskejä ottava, yritystään kasvattava mies. Toinen tutkimusaalto alkoi 1970-luvun loppupuolella, kun ensimmäiset naisyrittäjyystutkimukset ilmestyivät. Tämän vertailevan vaiheen, jossa naisia verrataan miesten luomaan todellisuuteen, lähtökohtana oli sukupuolineutraaliuden sijaan oletus nais- ja miesyrittäjistä. Miesten dominoiman yrittäjyyden historian löydöksiä pyrittiin soveltamaan naisiin tutkimalla samanlaisuuksia ja eroja. Tutkimusaalto tuotti kahdensuuntaisia tuloksia: nais- ja mies-yrittäjissä todettiin sekä samankaltaisuuksia että eroja. Näiden nähtiin koskevan yksilö- ja mikrotasoa sekä jossain määrin makrotasoa. Paula Kyrö nimeää naisten miehiin verrattuna erilaisen koulutuksellisen ja ammatillisen taustan yksilötasoiseksi eroksi, feministisestä näkökulmasta kyse on silloinkin yhteiskunnan sukupuolisegregaatiosta, joka näkyy sekä koulutus- että työmarkkinoilla (ks. esim. Naumanen 2002; Nurmi 2001).

Toisaalta tutkimuksissa havaittiin, että nais- ja miesyrittäjät eivät poikenneet toisistaan joidenkin tekijöiden suhteen. Tällaisia olivat sellaiset piirteet ja taipumukset kuin itsetunto, suorittamisen tarve, riskinotto- ja innovointitaipumus. Mikrotasolla naisten ja miesten omistamat yritykset toimivat eri maailmoissa, esimerkiksi toimialat olivat eriytyneet tutkimuksen mukaan. Naisten onnistuneisuuden kriteerit tulivat miesten luomasta yritysideaalista, johon verrattuna naisia kutsuttiin “alisuoriutujiksi”. 1990-luvun loppupuolella naisyrittäjyystutkimuksen kolmas aalto toi uudenlaisia sukupuolta koskevia näkökulmia yrittäjyystutkimukseen. Naisten yrittäjyyttä alettiin tutkia heidän omista lähtökohdistaan käsin. (Kyrö 2004, 300-304.) Tätä naiserityiseksi vaiheeksi tulkitsemaani suuntausta on seurannut sukupuolen kulttuurista tuottamista koskeva tutkimus (ks. Pietiläinen 2007), joka avaa keskustelua kohti sukupuolta koskevia mielikuvia ja merkityksiä.

Myös Tarja Pietiläinen (2007, 34-52) jäsentää naisyrittäjyystutkimusta kolmeen suuntaukseen. Jaottelu noudattaa Merja Kinnusen ja Päivi Korvajärven (1996, 16-17) ryhmittelyä suomalaisen työelämän pääsuuntauksista naistutkimuksessa, jolloin erotetaan toisistaan: 1. tasa-arvotutkimus, 2. naisten oman toiminnan tutkimus ja 3. sukupuolen tekemisen tutkimus. Ensimmäinen pääsuuntaus, tasa-arvotutkimus on tuottanut tietoa yrittäjänaisten eriarvoisesta asemasta ja osoittanut välineitä, joilla edistetään sukupuolten tasavertaisuutta yrittämisessä. Tämä lähtökohta ansioistaan huolimatta palauttaa kuitenkin kysymyksen sukupuolesta naisten ja miesten väliseksi jaoksi, kysymykseksi samanlaisuudesta ja erilaisuudesta (Pietiläinen 2007, 38; Kinnunen \& Korvajärvi 1996, 17).

Naisten oman toiminnan tutkimus toisena suuntauksena on tarkoittanut tutkimusta, jossa pyritään pois yhtenäisestä yrittäjänaisen kategoriasta. Kiinnostuksen kohteena ovat silloin yrittäjänaisten elämäntilanteet, velvoitteet ja tavoitteet suhteessa yritystoimintaan sekä naisten yrittämisen yhteiskunnalliset ehdot ja niiden muotoutuminen. Tätä suuntausta on arvosteltu essentialisoivasta, olemuksellistavasta sukupuolikäsityksestä, jolloin naisten ja miesten väliset suhteet jäsentyvät alistuksen ja patriarkaatin kautta. 
"Naisyrittäjille ominaisen tavan" etsiminen hukkaa naisten väliset erot. (Pietiläinen 2007, 39, 81.) Kolmantena suuntauksena on sukupuolen tekemisen tutkimus, jossa huomio kiinnitetään siihen, miten käytännöissä, vuorovaikutuksessa ja mielikuvissa luodaan ja uusinnetaan naisiin ja miehiin liittyviä merkityksiä. Nämä merkitykset järjestävät naisten ja miesten välisiä kulttuurisia ja yhteiskunnallisia suhteita. (Kinnunen ja Korvajärvi 1996, 19.)

Yrittäjyyden sukupuolen tutkimuksessa ongelmallista on naisten luokittelu jonnekin samuuden ja eron väliin suhteessa miesnormiin. Samuuteen perustuva lähtökohta näkee naiset ja miehet samanlaisina, mutta naisten mahdollisuuksia yrittämiseen on vahvistettava. Myös sukupuolten eroon keskittyvä, naisten erilaisuutta yrittäjinä korostava tutkimustapa suhteuttaa naiset miesnormiin. Niin nais- ja miesyrittäjyyteen kuin pelkästään naisyrittäjyyteen keskittyvä tutkimus voi tuottaa perinteistä heteronormatiivista järjestystä olettamalla malliksi heteroseksuaalisen pariskunnan ja perinteisen ydinperheen. ${ }^{6}$ (Ahl 2004, 190-191.) Heteronormatiivista järjestystä ylläpitävät ja uusintavat lukuisat kulttuuriset ja sosiaaliset olettamukset ja käytännöt. Erilaisen tutkimusotteen avulla voi välttää joiltakin osin sukupuolistereotypioiden vahvistamisen. Feministinen tutkimus on pyrkinyt tuomaan uusia näkökulmia keskusteluun tutkimalla sukupuolta tuottavia olosuhteita ja käytäntöjä naisten ja miesten samuuden tai eron sijasta. Miesja heteroseksuaalisen normin lisäksi yrittäjyystutkimukselle on hedelmällistä analysoida myös muita kulttuurisia ”itsestäänselvyyksiä”, esimerkiksi millaisia näkökulmia yrittäjien etniset taustat tuottavat (ks. esim. Gill \& Ganesh 2007) tai miten esimerkiksi maantieteellinen paikka määrittyy tutkimuksessa (Ronkainen \& Naskali 2007).

\section{Ulkoinen ja sisäinen yrittäjyys?}

Koska yrittäjyyskasvatus omaksuttiin brittiläisestä ja amerikkalaisesta koulutuspolitiikasta nopeasti suomalaiseen koulutusjärjestelmään pohtimatta maan erityislaatuisia olosuhteita, yrittäjyyskasvatuskäsitteen sisältö jäi hämäräksi, "harmaaksi alueeksi”, joka kaipaa selventämistä (Erkkilä 2000). Talouden diskurssin kehystämä yrittäjyyskasvatuksen edistäminen sisältyy sekä Suomen hallituksen että EU-komission ohjelmaan. Yrittäjyyden edistäminen kaikilla kouluasteilla sisältyi vuoden 2003 hallitusohjelmaan yhtenä politiikkaohjelmana.
Suomessa yrittäjyyskasvatuksesta on viime aikoina käyty keskustelua erilaisista näkökulmista (ks. esim. Ikonen 2007a ja 2007b; Keskitalo-Foley, Komulainen, \& Naskali 2007; Kyrö \& Ripatti 2006). Yrittäjyyskasvatusta voidaan ajatella sekä työvoimapolitiikkana että ideologiana (ks. Ikonen 2007b). Työvoimapoliittiseen näkökulmaan liittyy ajatus ulkoisesta yrittäjyydestä, jolla tarkoitetaan yrittäjyyttä ammattitaitona, ideologinen näkemys sisäisestä yrittäjyydestä koskee yrittäjämäisen asenteen luomista.

Ulkoisen ja sisäisen yrittäjyyden käsitteet on jäsennetty liikkeenjohdon tarpeita ajatellen, mutta kun termit on irrotettu tästä yhteydestä ja siirretty muille alueille, niiden merkityssisällöt voivat muuttua. Sisäisen yrittäjyyden käsitteelle tunnistetaan kolme erilaista ymmärrystä. Sisäisellä yrittäjyydellä voidaan tarkoittaa ensinnäkin emoyhtiöstä liikkeelle lähtenyttä, mutta edelleen sen vaikutuspiirissä toimivaa yritystä, jota hoitavat emoyhtiön entiset työntekijät. Toiseksi käsitteellä voidaan tarkoittaa palkansaajan toimintatapaa työorganisaatiossaan. Tällöin työntekijä toimii toisen palveluksessa yrittäjämäisesti, ikään kuin työskentelisi omassa yrityksessään. Kolmas merkitys sisäiselle yrittäjyydelle viittaa yleiseen elämänasenteeseen, jota määrittävät muun muassa aktiivisuus, luovuus, ahkeruus, oma-aloitteisuus ja päämäärätietoisuus. (Ikonen 2007a, 11.)

Edellisestä jaottelusta osittain poikkeava jäsennys hahmottaa yrittäjyyden kolmeen muotoon: ulkoinen, sisäinen ja omaehtoinen yrittäjyys. Tässä jaottelussa ulkoinen yrittäjyys käsitteenä kuvaa prosessia, jonka tunnuksena luodaan itsenäinen pienyritys, sisäinen yrittäjyys viittaa kollektiiviseen prosessiin, työyhteisön tai -organisaation yrittäjämäiseen toimintaan. Omaehtoinen yrittäjyys koskee yksilön omaa kehityskertomusta, hänen asenteitaan ja tapaansa toimia. Se viittaa yksilön roolin muutokseen työnjaon ja organisaatioistumisen tuotteena. Käsitteeseen liittyy vastuullisuus omasta työllistyvyydestä, se korostaa yksilön omaa vaikuttamista itseensä ja ympäristöönsä. (Kyrö 1997, 225-227. ) Vuonna 2007 ilmestyneessä yrittäjyyskasvatuksen julkaisussa (Kyrö, Lehtonen \& Ristimäki 2007, 18) yrittäjyys kiinnitetään neljään toistensa kanssa vuorovaikutuksessa olevaan muotoon, joita ovat 1 . yksilön yrittäjämäinen toimintatapa, 2. ulkoinen yrittäjyys eli pienyrityksen omistaminen ja johtaminen, 3.organisaatioyrittäjyys eli organisaation kollektiivinen toimintatapa ja 4. sisäinen yrittäjyys, joka liittyy 
yksilön ja organisaation yrittäjämäiseen toimintatavan dynamiikkaan.

Edellä esittelemissäni määrittelyissä ulkoinen yrittäjyys määrittyy jokseenkin yksiselitteisesti ammatillisena toimintana. Monimuotoiseksi hajaantunut sisäisen yrittäjyyden tai yrittäjäminän käsitteet ovat osoittautuneet hedelmälliseksi analyysin kohteeksi. Niitä on tarkasteltu kansalaisuuden (ks. esim. Ikonen 2007b) ja sukupuolen (ks. esim. Komulainen 2005 ja 2007) näkökulmasta. Risto Ikosen (2007b) mukaan sisäisen yrittäjyyden käsitteen vakavin puute on sen irrallisuus yhteiskunnallisesta kontekstista. Ei ole mitään loogisia esteitä sille, että sisäinen yrittäjyys voi saada tulkinnan, jossa yksilöstä tulee vapaan subjektin sijasta pelkästään työkalu. Tämä työkalu tekee annetut tehtävät, käskee ja valvoo itse itseään sekä esittää vielä parannusehdotuksia toimintaansa.

Äärimmäisenä esimerkkinä tästä voisi olla natsi-Saksan turvallisuuspoliisin toiminta, jossa työskennelleet henkilöt kuvattiin poikkeuksellisen omistautuneiksi työlleen. He veivät töitä mukaan kotiinsa, olivat sisäistäneet organisaationsa mission ja toteuttivat työtään kuin omana hankkeenaan. Tämänkaltainen oma-aloitteisuus, itsensä alistaminen tehtävälle ja sitoutuminen organisaatioon on kuitenkin yhteen sopimaton demokraattisen yhteiskunnan olettaman kansalaisideaalin kanssa, jossa odotetaan muun muassa valmiutta suhteuttaa omat pyrkimyksensä yhteisempiin, myös muiden ihmisten tavoitteisiin. "Elämänasenteeksi tarjottu sisäisen yrittäjyyden ajatus ei tuo aktiivisen kansalaisen ideaan mitään uutta. Sen sijaan se tuo muassaan kyseenalaisia sivumerkityksiä.” (Ikonen 2007b, 106-110.) Uudelleen määrittelyllä ja irrottamalla yrittäjyyden käsite uusliberalistisesta retoriikasta sekä palauttamalla se osaksi pohjoismaista hyvinvointivaltion ideaa yrittäjyyskasvatus voidaan liittää takaisin kansalaisyhteiskunnan diskurssiin (Ikonen 2006, 64).

Vaikka yrittäjyyttä ja yrittäjyyskasvatusta ajatellaan mahdollisuutena kaikille, maskuliiniseksi mielletty yrittäjyys muodostaa normin, johon nähden naisten yrittäjyys sekä työväenluokkaan assosioidut työn tekemisen piirteet on historiallisesti suljettu pois yrittäjyyden ja yrittäjämäisen toimintatavan ideaaleista. (Ahl 2002). Naisyrittäjyydestä on sekä tieteessä että arkipäivän ajattelussa muodostunut suhteellisen yhtenäinen näkökulma, jonka kautta maailmaa tulkitaan. Sanomalehtiaineiston analyysi vahvistaa tutkimuksia yrittäjyyden sukupuolistuneesta luonteesta: "(mies) yrittäjä määrittyy yrittäjäminältään autonomiseksi, kilpailuhenkiseksi johtajaksi, menestyksenhaluiseksi innovaattoriksi, nopeaksi päätöksentekijäksi”. (Komulainen 2005, 26-28.) Myös Anne Kontsaksen (2007) sanomalehtiaineistoon perustuva analyysi lappilaisesta kehitysoptimismista asettaa nuoret miehet Lapin tulevaisuuden tekijöiksi.

\section{Sivistys, tasa-arvo ja markkinat aikuiskasvatuksen keskusteluissa}

Aikuiskasvatuksen historiaa on jäsennetty erilaisina vaiheina ja erilaisten teemojen kautta. Nykypäivän suomalaista yhteiskuntaa on kuvattu moraalijärjestyksen murrosaikana, mikä näkyy myös aikuiskasvatuksen keskusteluissa. Kansakunnan demokraattisen kehityksen sijaan huomion ja huolen kohteena on työntekijöiden jaksaminen talouselämän toiminnan ja kansantalouden kustannusten kontekstissa. (Filander 2007.) Aulis Alasen (ks. Aaltonen 2006, 34) mukaan suomalainen aikuiskoulutuspolitiikka hahmottuu kolmeksi eri vaiheeksi: myötäilevän sivistyspolitiikan kauteen (19201960), suunnittelukeskeiseen politiikan kauteen (1970-1985) ja vuonna 1987 alkaneeseen markkinaperustaiseen vaiheeseen. Käsitteet, joilla kunkin aikakauden painotuksia kuvataan, ovat erilaisia. Myötäilevää sivistyspolitiikkaa kuvaavat"asiasanoina" vapaa kansanvalistus- ja sivistystyö ja aikuiskasvatus. Suunnittelukeskeiseen kauteen liitetään aikuiskoulutus, elinikäinen kasvatus, jatkuva kasvatus ja koulutus sekä jaksoittaiskoulutus. Markkinaperustainen vaihe kuvautuu oppimisen ajatuksen kautta: elinikäinen oppiminen, arkipäivän oppiminen ja elämänlaajuinen oppiminen.

Alasen jaottelussa markkinaperustainen vaihe voi viitata ensinnäkin aikuiskasvatuksen ja -koulutuksen järjestämiseen koulutusjärjestelmän ja työmarkkinoiden kesken. Institutionaalisena toimijana koulutusjärjestelmän tarjonnan tulisi vastata työmarkkinoiden kysyntää. Toinen tulkinta koskee koulutusta velvoitteena, yksilön jatkuvaa valmentautumista ja sopeutumista häneen mahdollisesti kohdistuvien odotusten ja vaatimusten varalta. Tämän ennakoinnin ja tulevaan varautumisen "perimmäisenä ajatuksena on se, että kukin yksilö toimii ikään kuin markkinayrityksenä, joka etsii tuotteelleen (itselleen) paikkaa markkinoilla käytävässä kilpailussa” (Koski \& Nummenmaa 1995, 345).

Julkinen keskustelu ${ }^{7}$ suomalaisesta (aikuis)koulutuspolitiikasta heijastelee brittiläistä poliit- 
tista siirtymää. Siinä ehdotetaan muutosta valtion ja yksilöiden keskinäisten velvollisuuksien suhteeseen vaatimalla yksilöllisten voimavarojen vahvempaa hyödyntämistä. Tämä uusliberalistiseksi nimetty toimintatapa pyrkii maksimoimaan yksilöiden taitojen hyödyntämisen ja minimoimaan heistä valtiolle koituva kulut (Tuschling \& Engemann 2006, 451-452). Nikolas Rosen (1992) mukaan hallinta (governance) toteutuu muun muassa kolmen toisiinsa liittyvän ulottuvuuden kautta. Poliittinen ulottuvuus koskee viranomaisten ja asiantuntijoiden keinoja vaikuttaa ihmisten ajatteluun ja toimintaan. Hallinnan institutionaalinen ulottuvuus viittaa esimerkiksi koulutusjärjestelmään, jossa koulutettaviin kohdistuvat oletukset ja tavoitteet rakentuvat ja toteutuvat koulutuksen käytännöissä. Eettinen ulottuvuus viittaa erilaisiin minäteknologioihin, käytäntöihin, joilla ihmiset muovaavat itseään, ominaisuuksiaan ja toimintatapojaan toivottavaksi nähtyyn suuntaan.

Aikuiskasvatukselle ominaisena piirteenä on pidetty yhteiskunnallisen tasa-arvon tavoittelua. Suomessakin kuten myös muualla Euroopassa aikuiskasvatusta tulkittiin vielä 1980-luvulla toisena mahdollisuutena, koulutuksen keinoin yhteiskunnalliseen tasa-arvoon mahdollistajana (Rinne, Heikkinen \& Salo 2007). Tasa-arvon ajatus tässä mielessä oli sukupuolineutraalia, mutta sukupuolen teema on löytänyt sijaa muun muassa aikuisopiskelijanaisten opiskelukokemuksien tutkimuksina (Edwards 1993; Merrill 1999). Myös lappilaisen maaseudun naisten koulutusta koskevassa tutkimuksessani (Keskitalo-Foley 2004, 111) aikuisopiskelusta tuotettiin pääosin myönteisiä, toisen mahdollisuuden emansipatorisia tarinoita. Opiskelun nähtiin avaavan teitä, mahdollisuutena muutokseen ja mieluisan elämäntavan valintaan. Uudistumisen mahdollisuuden ajatus voi olla vapauttava, mutta ajattelumallin vaarana on oletus historiattomasta, yhä uudelleen työmarkkinoiden muutosten mukaan kouluttautuvasta aikuisesta. Jos joku ei onnistu muuttamaan elämäänsä toivotulla tavalla ja samalla kuvittelee kaikkien muiden siihen pystyvän, yhteiskunnallisesta ja työmarkkinoiden muutoksesta tulee yksilön ongelma. (Vanttaja \& Järvinen 2006, 39-40; Walkerdine 2003, 239.)

Elinikäisen oppimisen ajatus sisällytetään aikuiskasvatuksen keskusteluihin itsestäänselvyytenä. Käsitteen kontekstin nähdään kuitenkin muuttuneen 1960-luvulta 2000 luvulle tultaessa. Kenneth Weinin (2004) mukaan elinikäisen koulu- tuksen ajatus liittyi 1960-luvulla ja 1970-luvun alussa tieteellisen humanismiin ja demokraattisen osallistumiseen pohjautuvan oppivan yhteiskunnan luomiseen. Silloisen koulutusjärjestelmän ${ }^{8}$ ei katsottu pystyvän vastaamaan muuttuvan maailman vaatimuksiin ja ratkaisuksi vaadittiin kaikille mahdollisen elinikäisten koulutuksen edistämistä. Koulutus tuli olla kaikkien ulottuvilla. UNECSO ilmoitti 1960-luvun alussa elinikäisen koulutuksen pääkäsitteeksi ohjaamaan 1900-luvun loppupuolen koulutussuunnittelua (mt., 2). Keskustelu jälkimodernista yhteiskunnasta on käynnistänyt tutkimuksia, joissa pyritään hakemaan aikuiskasvatukselle uutta paikkaa epävarmuuden ja ennakoimattomuuden ajassa (Filander 2000, 128).

Kulttuurin muutos on näkynyt myös käsitteistössä. Kun elinikäisen koulutuksen huomio oli 1990-luvulla siirtynyt laajemmasta yhteiskunnallisesta näkökulmasta pienempiin yksiköihin, sanastoon tuli muun muassa oppivan organisaation käsite (Wein 2004, 72). Organisaation ja yksilön oppimista koskeva käsitteistö korvasivat aiemman, yhteiskunnallisesti orientoituneen sanaston. Opetuskulttuuri on muuttunut: "kansalaiskasvatus on muuttumassa kilpailukykyisten yksilöiden valmentamiseksi ” (Värri 2007, 71).

\section{Lappilaiset naisyrittäjyyskoulutushank-} keet keskustelujen leikkauspisteessä

Olen tarkastellut artikkelissani yrittäjyyden sukupuolta sekä yrittäjyys- ja aikuiskasvatusta koskevaa tutkimusta lukemalla kutakin teemaa koskevia määrittelyjä, suuntauksia ja ajallisia jäsennyksiä.

Sukupuolen tutkimuksen näkökulmasta lappilaisten naisyrittäjyyshankkeiden koulutus asettuu vaiheeseen, jossa sukupuolta on mahdollista tarkastella monipuolisesti koulutuksessa ja työelämässä. Liikkuminen sukupuolineutraaliksi jätetystä tutkimuksesta sukupuolen tekemisen tutkimukseen siirtää huomion siihen, miten käytännöissä, vuorovaikutuksessa ja mielikuvissa luodaan ja uusinnetaan naisiin ja miehiin liittyviä merkityksiä. Yrittäjyyskäsitettä on problematisoitu sekä sukupuolen tutkimuksen että yrittäjyyskasvatuksen näkökulmasta. Naisten suhteuttaminen yrittäjyyden miesnormiin luo jännitettä sekä taloudellisessa että kulttuurisessa mielessä.

Lappilaisten naisyrittäjyyshankkeiden koulutus tapahtuu tilanteessa, jossa sekä talouden että yh- 
teiskunnallisen moraalijärjestyksen nähdään olevan murroksessa. Koulutus asettuu ajallisesti aikuiskoulutuksen markkinaperustaiseen vaiheeseen, yksilön kannalta epävarmaan ja ennakoimattomaan tilanteeseen. Aikuiskasvatuksen keskusteluissa painopiste on siirtynyt yhteiskunnallisesta näkökulmasta yksilökeskeisyyteen, jota kuvaa itseään ja toimintatapojaan toivottavaksi nähtyyn suuntaan jatkuvasti kehittävä "uusliberalistinen subjekti” (ks. esim. Rose 2002). Yleistä yksilökeskeistä ajattelua haastaa kuitenkin tasa-arvon teema, joka kiertyy mukaan lappilaiseen naisyrittäjyyskoulutushankkeisiin Euroopan unionin politiikan kautta. Kun tasa-arvon teema - niin aluetta, taloudellista kuin sukupuolta koskevana - yhtäältä näyttää lähes häipyneen kansallisesta koulutuspoliittisesta keskustelusta, se on liitetty naisyrittäjyyden edistämiseen tasa-arvotyöksi määriteltynä (ks. esim. Hyrsky 2006).

Uusliberalistinen ideologia korostaa yksilön vastuuttamista eikä kiinnitä huomiota toiminnan yhteiskunnallisiin ehtoihin, joita ovat esimerkiksi työmarkkinarakenteet. Petra Merenheimon (2008, 135-136) mukaan lappilaiset naisyrittäjät toimivat varsin eri tilanteessa kuin miesyrittäjät, sillä yrittäjien toimialat Lapissakin ovat paljolti sukupuolen mukaan segregoituneet. Naiset toimivat palvelualoilla sekä kaupan alalla, ja miehet teollisuuden, kuljetuksen, rakentamisen ja tietoliikenteen aloilla. Tämä toimialajako- ja keskittymä on ongelmallinen naisille, sillä julkinen tuki ohjautuu miesten aloille, samoin naisyrittäjät työnantajina kantavat myös suuremmat vanhemmuudesta aiheutuvat kustannukset. Paula Alho ja Arja Kallioniemi (2008, 27) huomauttavat, että yhtäläisten tasa-arvotulosten saavuttamiseksi ei riitä, että ainoastaan mahdollisuuksia annetaan, vaan tulosten tasa-arvon saavuttamiseksi sukupuolten tasa-arvoa on edistettävä aktiivisin toimenpitein. Jos Lappiin pätee tulkinta pohjoiskarjalaisen maaseudun tilanteesta: "Yrittäjyys ei ole irrottanut naista maaseudun sukupuolijärjestelmästä ja naisen paikasta" (Koski ja Tedre 2004, 123), ja "oikea” yrittäjä yleisessä ajattelussa edelleen on mies, mikä tila tässä asetelmassa tarjoutuu lappilaisille naisille?

Yrittäjyyskasvatuksen käsite asettuu jännitteiseksi ideologian ja työvoimapolitiikan kesken. Kysymys on diskurssista, joka sisältää aineksia kahdesta keskenään yhteen sopimattomasta aatevirtauksesta (Ikonen 2007b, 110 ). Ideologisesti tulkittuna yrittäjyyskasvatus tarkoittaa yrittäjämäisen asenteen, sisäisen yrittäjyyden virittämistä.
Hankekoulutus on usein osa työvoimapoliittista aikuiskoulutustarjontaa, jota voidaan pitää myös koulutuksellisena hyvinvointipalveluna (Viinamäki 1993, 16). Millainen yrittäjyyden ja yrityskasvatuksen uudelleen määrittely tarvittaisiin yrittäjyyden käsitteen irrottamiseksi uusliberalistisesta retoriikasta ja sen palauttamiseksi osaksi pohjoismaista hyvinvointivaltion ideaa (ks. Ikonen 2006, 64)?

Jos aikuiskasvatuksen ja koulutuksen painopiste nähdään siirtäneen painotusta yhteiskunnallisesta lähtökohdasta yksilöllisempään suuntaan, miten tämä ajatus on omaksuttu koulutusinstituutioissa? Miten esimerkiksi hankekoulutuksen toteuttajat näkevät tehtävänsä merkityksen? Haastattelemani hankekoulutuksen organisoija kuvaa työtään:

Hanketyön mie nään, et se poikkeaa koulutuksesta niinku sillä lailla, että mie nään sen semmosena et siinä on, siinä on lupa niinkö kokeilla ja ettiä niitä hyviä, kehittää menetelmiä ja niitä hyviä menetelmiä että mitkä sitte toimii (...) koulutus on minun mielestä suoraviivasempaa että siinä noudatetaan jotain tiettyä ohjelmaa, jota mennään sitte eteenpäin. Että hanketyö on enemmän semmosta kokeilevampaa. Ja sitte mie nään hanketyössä myös sen, että se (...) sillä, ainaki sillä pitäs olla niinkö vaikuttavuutta sitten laajemmalle alueelle ku pelkästään se, mikä on suoranainen kohderyhmä eli se opiskelijaryhmä. Eli että sillä pystyttäs niinkö alueelle, päättäviin tahoihin, ja jopa niinku sitten, jopa valtakunnallisestikin niinkö vaikuttamaan joihinkin toimintoihin, tai asenteisiin tai ainaki nostaan esiin joitaki asioita, joista voi keskustella. (Irja)

Irja hahmottaa hanketyötä kokeilevana, yhteiskunnallisesti vaikuttavana ja keskustelua virittävänä. Se mahdollistaa totuttujen käsitysten haastamisen ja uusien näkökulmien esiintuomisen. Vaikuttamisen kohteeksi ei asetu vain opiskelijaryhmä vaan hankkeella nähdään myös yhteiskunnallista vaikuttavuutta. Hanketyö instituutiona kuvautuu aktiiviseksi osallistujaksi; vaikuttamisen tavoite ja suunta on pienestä laajempaan, alhaalta ylöspäin, yksittäisestä hankekoulutuskokemuksesta kohti päättäjiä ja julkista keskustelua.

Tämän artikkelin kirjoittaminen lähti tarpeesta perehtyä keskeisimpiin lappilaista naisyrittäjyyshankekoulutusta määrittäviin keskusteluihin. Toin esiin keskusteluissa tunnistettuja jännitteitä, jotka syntyvät erilaisten diskurssien kohdatessa. Nämä jännitteet haastavat pohtimaan vallitsevien 
diskurssien merkitystä lappilaisten naisten toimijuuden tilan määrittäjinä. Tutkimukseni edetessä kohdistan huomioni siihen, millaisiin suhteisiin nämä keskustelut, teemat ja jännitteet asettuvat koulutushankkeita organisoineiden ja koulutukseen osallistuneiden naisten kertomusten kanssa.

\section{Lähteet}

Aaltonen, Rainer (2006). Käsitteet liikkeessä. Teoksessa Tuomisto, Jukka \& Salo, Petri (toim.) Edistävä ja viihdyttävä aikuiskasvatus. Tampere: Tampere University Press, 33-44.

Ahl, Helene (2004). The Scientific Reproduction of Gender Inequality. A Discourse Analysis of Research texts on Women's Entrepreneurship. Malmö: Liber AB.

Alho, Paula \& Kallioniemi, Arja (2007). Sukupuolten välinen tasa-arvo aluekehitystyössä. EU:n ohjelmakausi 2007-2013 ja Lapin kansalliset rakennerahasto-ohjelmat tasa-arvon edistämisen näkökulmasta. Teoksessa Ahola, Aino-Maija, Alho Paula, Heikkilä, Irmeli, Kallioniemi, Arja \& Merenheimo, Petra (toim.) Veni, Vidi, Turbavi - Tasa-arvorata alueella, työyhteisöissä ja yrittäjyydessä. Rovaniemi: Lapin yliopisto, 3-34.

Bertland, Lauren \& Warner, Michael (1998). Sex in Public. Critical Inquiry 24 (Winter), 547566.

Edwards, Rosalind (1993). Mature Women Students: separating or connecting family and education. London: Taylor \& Francis.

Erkkilä, Kristiina (2000). Entrepreneurial Education. Mapping the Debates in the United States, the United Kingdom and Finland. New York \& London: Garland Publishing Inc.

Gill, Rebecca \& Ganesh, Shiv (2007). Empowerment, Constraint, and the Entrepreneurial Self: A Study of White Women Entrepreneurs. Journal of Applied Communication Research, 35 (3) August, 268-293.

Filander, Karin (2000). Kehittämistyö murroksessa: sitoutuminen, sopeutuminen ja vastarinta julkisella sektorilla 1990-luvulla. Acta Universitatis Tamperensis 777.

Filander, Karin (2007). Aikuisuus, sosiaalipedagogiikka ja uusi moraalijärjestys. Sosiaalipedagoginen aikakausikirja, 10-vuotisjuhlajulkaisu. Kuopio: Suomen sosiaalipedagoginen seura ry. 151-165.
Holli, Anne Maria (2002). Suomalaisen tasa-arvopolitiikan haasteet. Teoksessa Holli, Anne Maria, Saarikoski, Terhi \& Sana, Elina (toim.) Tasa-arvopolitiikan haasteet. Helsinki:

Tasa-arvoasian neuvottelukunta, Sosiaali- ja terveysministeriö, 12-30.

Hyrsky, Kaisa (2006). Naisyrittäjyyden edistäminen - kasvatusta ja tukea naisten omilla ehdoilla. Teoksessa Kyrö, Paula \& Ripatti, Anna (toim.) Yrittäjyyskasvatuksen uusia tuulia. Yrittäjyyskasvatuksen julkaisusarja 4/2006. Tampereen yliopiston kauppakorkeakoulu.

Ikonen, Hanna-Mari (2003). Maaseudun naiset yrittäjinä - toimijoina, kohteina vai piilossa? Alue ja ympäristö, 32 (1), 46-56.

Ikonen, Hanna-Mari (2008). Maaseudun naiset yrittäjinä. Acta Universitatis Tamperensis 1291. Tampere.

Ikonen, Risto (2006). Yrittäjyyskasvatus. Kansalaisen taloudellista autonomiaa etsimässä. SoPhi 102. Helsinki ja Jyväskylä: Minerva.

Ikonen, Risto (2007a). Mitä on yrittäjyyskasvatus? Teoksessa Ikonen, Risto \& Karttunen, Eeva (toim.) Kytkentöjä yrittäjyyskasvatukseen. Näkökulmia taloudellisen yritteliäisyyden edistämiseen. Pohjois-Karjalan ammattikorkeakoulun julkaisuja A: Tutkimuksia 18, 9-26.

Ikonen, Risto (2007b). Yrittäjyyskasvatuksen kahdet kasvot. Teoksessa Ikonen, Risto \& Karttunen, Eeva (toim.) Kytkentöjä yrittäjyyskasvatukseen. Näkökulmia taloudellisen yritteliäisyyden edistämiseen. PohjoisKarjalan ammattikorkeakoulun julkaisuja A: Tutkimuksia 18, 97-112.

Jokinen, Eeva (2005). Aikuisten arki. Helsinki: Gaudeamus.

Jääskö, Outi (2000). Naiset porotaloudessa - piikoja vai poromiehiä? Teoksessa Högbacka, Riitta \& Trast, Terhi (toim.) Monessa mukana. Näkymiä naisten työhön ja elämään maaseudulla. Maaseutupolitiikan yhteistyöryhmän julkaisu. Sisäasiainministeriö.

Kantola, Anu (2002). Markkinakuri ja managerivalta. Poliittinen hallinta Suomen 1990luvun talouskriisissä. Helsinki: LoKi.

Keskitalo-Foley, Seija (2004). Kohti kuulumisen maisemia. Toimijuuden tilat ja paikat lappialisen maaseudun naisten elämäkerroissa. Acta Universitatis Lapponiensis 78. Lapin 
yliopisto. Rovaniemi.

Keskitalo-Foley, Seija, Komulainen, Katri \& Naskali, Päivi (2007). Yrittäjäminuuden sukupuoli koulutuksessa. Kasvatus, 38 (2), 110-121.

Kinnunen, Merja \& Korvajärvi, Päivi (1996). Lopuksi: työelämän sukupuolistaminen. Teoksessa Kinnunen, Merja \& Korvajärvi, Päivi (toim.) Työelämän sukupuolistavat käytännöt. Tampere: Vastapaino, 233-240.

Komulainen, Katri (2004). Suomalainen - löydä sisäinen yrittäjyytesi! Kansa, kansalaisuus ja erot yrittäjäkasvatuksen oppikirjoissa. Kasvatus, 35 (5), 541-555.

Komulainen, Katri (2005). Sukupuolitettu yrittäjäminä. Sanomalehtiaineiston analyysi. Naistutkimus - Kvinnoforskning, 18 (4), 18-30.

Komulainen, Katri (2007). (Palkka)työläisestä yrittäjäksi? Yrittäjyyden sankaritarina, yrittäjäminä ja erot Yritys Hyvä!-kirjoituskilpailuaineissa. Teoksessa Ikonen, Risto \& Karttunen, Eeva (toim.) Kytkentöjä yrittäjyyskasvatukseen. Näkökulmia taloudellisen yritteliäisyyden edistämiseen. Pohjois-Karjalan ammattikorkeakoulun julkaisuja A: Tutkimuksia 18.

Kontsas, Anne (2007). Nuoret, Lappi ja tulevaisuus. Maskuliininen kehitysoptimismi sanomalehtiuutisessa. Teoksessa Autti, Mervi, Keskitalo-Foley, Seija, Naskali, Päivi \& Sinevaara-Niskanen, Heidi (toim.) Kuulumisia. Feministisiä tulkintoja naisten toimijuuksista. Rovaniemi: Lapin yliopistokustannus, 318-343.

Koski, Leena \& Nummenmaa, Anna Raija (1995). Kilpailu kouludiskurssissa. Kasvatus, 31 (4), 340-384.

Koski, Leena \& Tedre, Silva (2004). Maaseudun naisyrittäjien työnteon ehdot. Työelämän tutkimus, 2(2-3), 123-134.

Kovalainen, Anne (1993). At the margins of economy. Women's Self-Employment in Finland 1960-1990. Turun kauppakorkeakoulun julkaisuja, sarja A 9.

Kyrö, Paula (1997). Yrittäjyyden muodot ja tehtävä ajan murroksessa. Jyväskylä studies in computer science, economics and statistics 38. Jyväskylä.

Kyrö, Paula (2004). Naisyrittäjien toisenlainen todellisuus. Aikuiskasvatus, 14 (4), 295-308.

Kyrö, Paula \& Ripatti, Anna (2006). Yrittäjyyskasvatuksen uusia tuulia. Yrittäjyyskasva- tuksen julkaisusarja 4/2006. Tampereen yliopiston kauppakorkeakoulu.

Kyrö, Paula, Lehtonen, Heleena \& Ristimäki, Kari (2007). Yrittäjyyskasvatuksen suuntia etsimässä. Teoksessa Kyrö, Paula, Lehtinen, Heleena \& Ristimäki, Kari (toim.)Yrittäjyyskasvatuksen monia suuntia. Yrittäjyyskasvatuksen julkaisusarja 5/2007. Tampereen yliopiston kauppakorkeakoulu, 13-30.

Laitinen, Matti \& Nurmi, Kari (2007). Aktiivinen kansalainen yrittäjänä. Teoksessa Kyrö, Paula Lehtinen, Heleena \& Ristimäki, Kari (toim.) Yrittäjyyskasvatuksen monia suuntia. Yrittäjyyskasvatuksen julkaisusarja 5/2007. Tampereen yliopiston kauppakorkeakoulu, 78-100.

Ljungren, Elisabeth \& Nilsson, Pernilla (1996). Female Entrepreneurs in Scandinavia. An Institutional Perspective on Entrepreneurship. Teoksessa Tuohimaa, Sinikka, Työlahti, Nina \& Fyhn, Asbjorg (toim.) On the Terms of Northern Woman. Femina Borealis Publication. Series Number 1, 184-198.

Merenheimo, Petra (2008). Lapin naisyrittäjät. Teoksessa Ahola, Aino-Maija, Alho Paula, Heikkilä, Irmeli, Kallioniemi, Arja \& Merenheimo, Petra (toim.) Veni, Vidi, Turbavi - Tasaarvorata alueella, työyhteisöissä ja yrittäjyydessä. Rovaniemi: Lapin yliopisto, 104-140.

Merrill, Barbara (1999). Gender, Change and Identity: Mature Women Students in Universities. Aldershot: Ashgate.

Naumanen, Päivi (2002). Koulutuksella kilpailukykyä: koulutuksen yhteys miesten ja naisten työllisyyteen ja työn sisältöön. Koulutussosiologian tutkimuskeskus 57. Turun yliopisto.

Nurmi, Kaarina (2001). Koulutus- ja työmarkkinoiden eriarvoistavat sukupuolijaot. Teoksessa Arto Jauhiainen, Risto Rinne \& Juhani Tähtinen (toim.) Koulutuspolitiikka Suomessa ja ylikansalliset mallit. Suomen Kasvatustieteellinen Seura. Kasvatusalan tutkimuksia 1, 205-225.

Olssen, Mark (2003). Structuralism, post-structuralism, neo-liberalism: assessing Foucault's legacy. Journal of Educational Policy, 18 (2), 189-202.

Opetusministeriön yrittäjyyskasvatuksen linjaukset ja toimenpideohjelma 2004. Opetusministeriön julkaisuja 2004:18. http:www.minedu.fi/ julkaisut/koulutus/2004/opm18/opm18pdf. 
Pietiläinen, Tarja (2007). Moninainen yrittäminen. Sukupuoli ja yrittäjänaisten toimintatila tietoteollisuudessa. Elektroninen aineisto. Alkup. julkaistu 2002 Helsinki School of Economics. Acta Universitatis Oeconomiae Helsingiensis A - 207.

Rinne, Risto, Heikkinen, Anja \& Salo, Petri (2007). Liberty, Fraternity, Equality - a French Introduction to Nordic Adult Education. Teoksessa Rinne, Risto, Heikkinen, Anja \& Salo, Petri 2007. Adult education - Liberty, Fraternity, Equality? Nordic Views on lifelong learning Kasvatusalan tutkimuksia 28. Suomen kasvatustieteellinen seura, 9-15.

Ronkainen, Suvi \& Naskali, Päivi (2007). Paikka ja paikattomuuden etuoikeus. Naistutkimus Kvinnoforsking, 2, 65-71.

Rose, Nikolas (1992). Governing the Enterprising Self. Teoksessa Paul Heelas \& Paul Morris (toim.) The Values of the Enterprise Culture. The Moral Debate. London \& New York: Routledge, 141-164.

Räsänen, Leila (1990). Kokeilun lähtökohdat ja opetukset. Teoksessa Leila Räsänen (toim.) Vammalan naisyrittäjäkurssi - kvinnoföretagarkursen i Vammala. Pohjoismainen AVAAprojekti. Det Nordiska BRYT-projektet. Nro 27/1990. Työministeriö.

Tuschling, Anna \& Engemann, Cristoph (2006). From Education to Lifelong Learning: The Emerging regime of learning in the European Union. Educational Philosophy and Theory, 38(4), 451-469.

Vanttaja, Markku \& Järvinen, Tero (2006). Oppiminen ja identiteetti muuttuvassa yhteiskunnassa. Teoksessa Mäkinen, Jarkko, Olkinuora, Erkki, Rinne, Risto ja Suikkanen, Asko (toim.) Elinkautisesta työstä elinikäiseen oppimiseen. Jyväskylä: PS-kustannus, 27-42.

Walkerdine, Valerie (2003). Reclassifying Upward Mobility: Femininity and the Neo-Liberal Subject. Gender and Education, 15 (3), 237-248.

Wein, Kenneth (2004). The Learning Society in a Postmodern World. New York: Peter Lang.

Viinamäki, Leena (1993). Vielä sitä vanhanakin voi opiskella. Tutkimus työvoimapoliittisen intervention mahdollisuuksista. Työpoliittinen tutkimus 61. Helsinki: Työministeriö.

Westman, Liisa (2006). Eurooppalaista mahdollistamista - keinona naisten resurssikeskuk- set. <http://www.piramk.fi/kever/kever.nsf/ 6f20c22b03be2d6cc2256b4c004a0b2f/2b34263 d051725b7c2257129006c8304!OpenDocument>

Värri, Veli-Matti (2007). Kasvatusfilosofian tärkein tehtävä. Niin \& näin, 52 (1), 70-73.

Muut lähteet: Haastattelu Irja syksyllä 2007

\section{Viitteet}

1. Osaksi suomalaista koulutuskeskustelua yrittäjyyskasvatus tuli jo 1980-luvulla ja 1990-luvulla myös koulujen opetussuunnitelmiin (Ikonen 2006, 13-15).

2. www.joensuu/psykologia/yrittajamina/

3. Koska tutkimus on vielä meneillään, en ole vielä yksilöinyt aineistoni hallinnollisia asiakirjoja. Eettisistä syistä en nimeä naisyrittäjyyshankkeita, joita tutkimukseni koskee.

4. Uusliberalismi eroaa klassisesta liberalismista suhtautumisessa valtiovaltaan. Klassisen liberalismin mukaan yksilö tulee vapauttaa valtion vaikutuspiiristä ja valtio tulee pitää poissa markkinoilta. Uusliberalismi korostaa valtion myönteistä tehtävää toimijana, joka aktiivisesti luo sopivat olosuhteet tarjoamalla tavoitteilleen tarvittavat olosuhteet, lait ja instituutiot. Kasvatus- ja koulutusjärjestelmä on tällöin keskeinen väylä luoda valtion tavoittelema yksilö, joka on tarmokas ja kilpailukykyinen yrittäjä. (Komulainen 2007, 114; Olssen 2003.)

5. Yrittäjyyden on katsottu tarjoavan vapautta ja muita resursseja aktiivisena kansalaisena toimimiselle (Laitinen \& Nurmi 2007, 90-91).

6. Lauren Bertlandin ja Michael Warnerin (1998, 555-556) mukaan heteronormatiivisuus on keskeinen sosiaalisen yhteisön rakentumisen sääntö. Perheellistymisen oletus kulttuurisena itsestäänselvyytenä on yksi "julman normaaliuden” näkyvimpiä muotoja (Jokinen 2005, 142-143).

7. Tällä viittaan siihen, miten politiikan ja talouden vaikuttajat ovat korostaneet yksittäisten ihmisten vastuuta yleisestä kuntoisuudestaan. Työntekijöiden jaksamisesta kiinnostutaan valtion kustannusten kontekstissa. (ks. Filander 2007.)

8. 1960-luvulla suomalaisessa yhteiskunnassa toimi rinnakkaiskoulujärjestelmä, jossa ihmiset jakautuivat jo varhaisessa vaiheessa kahteen eri "koulutusputkeen”.

Artikkeli saapui toimitukseen 20.2.2008. Se hyväksyttiin julkaistavaksi toimituskunnan kokouksessa 21.4.2008. 